\title{
THE MODERN WORLD-SYSTEM III
}

The Second Era of Great Expansion of the

Capitalist World-Economy, 1730-1840s 


\title{
ENCYCLOPEDIE,
}

$\mathrm{O} \mathrm{U}$

DICTIONNAIRE RAISONNÉ

DE S S I E N C E S,

DES ARTS ET DES MÉTIERS,

\author{
PAR UNE SOCIETE DE GENS DE LETTRES.
}

\begin{abstract}
Mis en ordre \& publié par M. DIDEROT, de IAcadémie Royale des Sciences \& des BellesLettres de Pruffe; \& quant à la PArtie Mathématique, par M. D'ALEMBERT, de l'Académie Royale des Sciences de Paris, de celle de Pruffe, \& de la Société Royale
\end{abstract} de Londres.

Tantùm feries juncturaque pollet,

Tantìm de medio fumptis accedie honoris! HoRAT.

T OME PREMIER.

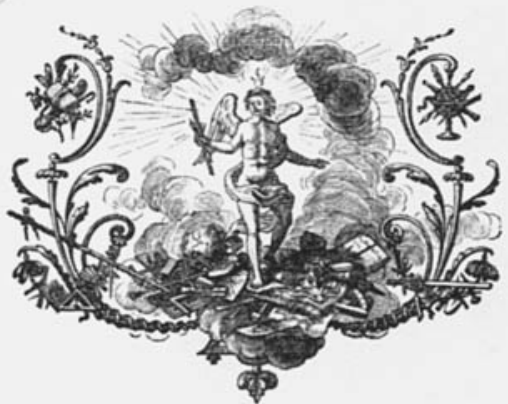

A P A R I S,

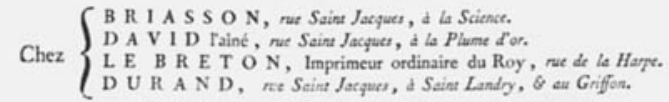

M. D C C. L I.

AVEC APPROBATION ET PRIVILEGE DUROY.

Diderot's Encyclopedia is considered the quintessential intellectual expression of the Enlightennent and has long symbolized for many the triumph of scientific rationalism as the reigning ideology of the modern world-system. Writen by benis Dideron with the aid of Jeatn le Rond d'Alembert for the mathematical part, it was published originally from 1751 to 1780 ), in 35 volumes in folio, of which 21 were tex1, 12 contained plates, and 2 contaned tables constructed by P. Mouchour. 


\section{THE}

\section{MODERN WORLD-}

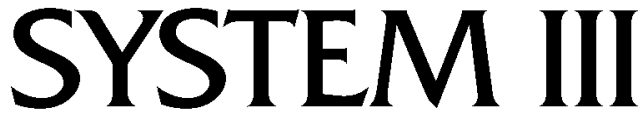

The Second Era of Great Expansion of the

Capitalist World-Economy 1730-1840s

WITH A NEW PROLOGUE

Immanuel Wallerstein

फ

UNIVERSITY OF CALIFORNIA PRESS

Berkeley Los Angeles London 
University of California Press, one of the most distinguished university presses in the United States, enriches lives around the world by advancing scholarship in the humanities, social sciences, and natural sciences. Its activities are supported by the UC Press Foundation and by philanthropic contributions from individuals and institutions. For more information, visit www.ucpress.edu.

University of California Press

Berkeley and Los Angeles, California

University of California Press, Ltd.

London, England

Previously published in 1989 by Academic Press, Inc.

(C) 2011 by The Regents of the University of California

ISBN 978-0-520-26759-6 (pbk. : alk. paper)

The Library of Congress has catalogued an earlier edition

of this book as follows:

Library of Congress Cataloging-in-Publication Data

Wallerstein, Immanuel Maurice, Date.

The second era of great expansion of the capitalist world-economy, 1730 s-1840s / Immanuel Wallerstein.

p. $\mathrm{cm}$.

Bibliography: $\mathrm{p}$.

Includes index.

ISBN 0-12-785925-X (hardcover) (alk. paper)

ISBN 0-12-785926-8 (paperback) (alk. paper)

1. Economic history-1600-1750. 2. Economic history-1750-1918.

3. Europe-Economic conditions-18th century. 4. Europe-Economic conditions-19th century 5.Capitalism-History. I. Title.

II. Series. III. Series: Wallerstein, Immanuel Maurice, Date Modern

world-system ; 3 IV. Series: Studies in social discontinuity.

HC51.W28 1974 vol. 3

[HC52]

$330.94^{\prime} 02 \mathrm{~s}-\mathrm{dc} 19$

[330.94'0253]

$88-10457$

Manufactured in the United States of America

$$
\begin{aligned}
& \begin{array}{llllllllll}
20 & 19 & 18 & 17 & 16 & 15 & 14 & 13 & 12 & 11
\end{array} \\
& \begin{array}{llllllllll}
10 & 9 & 8 & 7 & 6 & 5 & 4 & 3 & 2 & 1
\end{array}
\end{aligned}
$$

This book is printed on 50\# Enterprise, a $30 \%$ post consumer waste, recycled, de-inked fiber and processed chlorine free. It is acid-free, and meets all ANSI/NISO (Z 39.48) requirements. 
To Beatrice 
This page intentionally left blank 